\title{
Cervical softening in late pregnant sheep by infusion of prostaglandin E-2 into a cervical artery
}

\author{
W. L. Ledger†, D. A. Ellwood $\dagger$ and M. J. Taylor* \\ Department of Clinical Veterinary Medicine, University of Cambridge, Madingley Road, \\ Cambridge CB3 OES and $\uparrow$ Nuffield Department of Obstetrics \& Gynaecology University of Oxford, \\ John Radcliffe Hospital, Headington, Oxford OX3 9DU, U.K.
}

\begin{abstract}
Summary. Cervical softening was induced in late pregnant sheep by infusion of PGE-2 into a cervical artery. The effect of this treatment was assessed by measurement of the extensibility in vitro of a strip of cervical tissue. After infusion of a saline/ethanol mixture extensibility was $2.84 \times 10^{-3} \pm 0.3 \times 10^{-3} \mathrm{~min}^{-1}($ mean \pm s.e.m., $\mathrm{N}=5$ ); after infusion of PGE-2 it increased significantly $(P<0.02)$ to $8.6 \times 10^{-3} \pm 1.8 \times$ $10^{-3} \mathrm{~min}^{-1}(\mathrm{~N}=6)$. Infusion of PGE-2 did not increase uterine activity, and there was no significant change in the concentration of progesterone in the maternal jugular venous plasma. These data suggest that PGE-2 might act as a mediator of cervical softening in vivo and show that the cervix can soften in the absence of uterine contractions.
\end{abstract}

\section{Introduction}

Prostaglandins (PGs) have been implicated in the mechanism of cervical softening at parturition in various species (Liggins, Fairclough, Grieves, Forster \& Knox, 1977; Cooke, Knifton, Fitzpatrick \& Ward, 1977; Fitzpatrick, 1977a; Hollingsworth, Gallimore \& Isherwood, 1980; Ellwood, Mitchell, Anderson \& Turnbull, 1980b). In late pregnant sheep the involvement of PGs has been investigated in a number of ways. Firstly, cervical softening was induced by intra-aortic or intravenous infusion, or by infusion directly into the cervical lumen, of PGE-2 and PGF- $2 \alpha$, although the response was variable (Liggins et al., 1977; Fitzpatrick, 1977b; Fitzpatrick \& Dobson, 1981). Secondly, it has been shown that the cervix of the pregnant sheep can produce prostanoids both in vitro and in vivo. Synthesis of PGE and 6-keto-PGF-1 $\alpha$ (the major metabolite of prostacyclin) by cervical tissue in vitro is increased immediately after delivery when compared to values in late pregnancy (Ellwood et al., 1979, 1980a). Thirdly, treatment with meclofenamic acid (an inhibitor of PG synthesis) is associated with a degree of cervical dystocia when labour is induced by intra-fetal infusion of dexamethasone (Mitchell \& Flint, 1978).

Despite these investigations, softening of the ovine cervix by a direct action of PGs on cervical tissue has yet to be demonstrated satisfactorily. In particular, it is important to use methods which exclude a softening effect secondary to induction of uterine contractions by the PG treatment, as well as to use an objective test to measure the effect of the treatment on the cervix. To meet these criteria we have attempted to deliver PGE-2 directly to the cervix by infusion through a catheter

* Reprint requests to: Dr M. J. Taylor, Department of Physiology and Pharmacology, lowa State University, 2008 Veterinary Medicine Building, Ames, lowa 50011, U.S.A. 
placed in a cervical artery and have measured cervical softening in vitro using a test of the mechanical properties of the tissue.

\section{Materials and Methods}

Eleven Suffolk crossbred ewes of known gestational ages and similar size were used (Table 1). Catheters were surgically implanted between Days 111 and 124 of pregnancy. General anaesthesia was induced by rapid intravenous injection of $1 \mathrm{~g}$ thiopentone sodium, and maintained with $2-4 \%$ halothane in an oxygen/nitrous oxide mixture in a closed-circuit system. The maternal jugular vein and amniotic cavity were catheterized with polyvinyl chloride catheters (i.d. $2.0 \mathrm{~mm}, 0$. d. $3.0 \mathrm{~mm}$; Portex, Hythe, Kent, U.K.) using aseptic procedures. The arterial supply to the cervix was catheterized essentially as described by Ellwood, Anderson, Mitchell, Murphy \& Turnbull (1981). Following an initial midline abdominal incision extending from the umbilicus to the upper border of the mammary gland, the retro-peritoneal space beneath the mammary gland was undermined by blunt dissection. The abdominal wall incision was then extended beneath the mammary gland to expose the lower end of the uterus and the utero-cervical junction. The upper end of the cervix was partly withdrawn from the pelvis and carefully stripped of its peritoneal covering. The artery to be catheterized was identified and exposed by blunt dissection, then ligated cranially to the site of insertion of the catheter. A PP 90 catheter (i.d. $0.8 \mathrm{~mm}$, o.d. $2.0 \mathrm{~mm}$; Portex) was then advanced approximately $5 \mathrm{~cm}$ along the artery, until the tip of the catheter could be palpated at the mid-point of the cervix. The catheter was then tied in place and the cervix returned to the pelvis. Intraabdominal catheters were exteriorized via a stab wound in the left flank. The ewes were kept in pens after operation and fed $1 \mathrm{~kg}$ sheep concentrates per day; hay and water were always available. Oxytetracycline (600 mg Terramycin; Pfizer Ltd, Sandwich, Kent, U.K.) was injected once intramuscularly on the day of operation and on the following 3 days. Catheters were flushed daily with sterile saline $(9 \mathrm{~g} \mathrm{NaCl} / \mathrm{l})$ containing 250 units heparin $/ \mathrm{ml}$.

Experiments were begun at least 7 days after surgery (Table 1). Before the experiments, $5 \mathrm{mg}$ PGE-2 in $0.5 \mathrm{ml}$ ethanol (Prostin-E2; Upjohn Ltd, Crawley, Sussex, U.K.) were added to $16 \mathrm{ml}$ heparinized saline and the mixture was then infused through the cervical arterial catheter using a constant rate infusion pump. The solution of PGE-2 was made up immediately before use and changed after $24 \mathrm{~h}$, each infusion lasting for $48 \mathrm{~h}$ and giving a total PGE-2 infusion of $10 \mathrm{mg}$. Ewes

Table 1. Experimental data on Ewes 1-6 infused with PGE-2 (10 mg) and Ewes 7-11 infused with ethanol and saline in late gestation

\begin{tabular}{lcccc}
\hline \multirow{2}{*}{ Infusion } & & \multicolumn{2}{c}{ Gestational age (days) } & \\
\cline { 3 - 4 } & Ewes & At operation & At start of infusion & $\begin{array}{r}\text { No. of } \\
\text { lambs* }\end{array}$ \\
\hline PGE-2 & 1 & 111 & 118 & 2 \\
& 2 & 114 & 122 & 1 \\
& 3 & 118 & 126 & 2 \\
& 4 & 118 & 128 & 2 \\
Saline & 5 & 122 & 129 & 2 \\
& 6 & 124 & 132 & 2 \\
& 7 & 111 & 119 & 2 \\
& 8 & 112 & 120 & 1 \\
& 10 & 120 & 130 & 2 \\
\hline
\end{tabular}

* All lambs were alive at time of death of the ewe. 
1-6 received this treatment and Ewes 7-11 were used as controls, receiving a mixture of ethanol and heparinized saline alone by infusion at the same rate. Ewes were restrained in metabolism cages during the whole period of infusion. Intra-amniotic pressure changes were recorded through an open-ended fluid-filled amniotic catheter using a type 4-442 physiological pressure transducer (Bell \& Howell Ltd, Basingstoke, Hants, U.K.) connected to an amplifier and hot-wire recorder (Devices Ltd, Welwyn Garden City, Herts, U.K.).

Immediately before the start of each infusion, and at intervals of approximately $6 \mathrm{~h}$ thereafter, jugular venous blood samples were withdrawn into heparinized syringes, transferred at once into chilled polystyrene tubes and centrifuged for $15 \mathrm{~min}$ at $900 \mathrm{~g}$ at $4^{\circ} \mathrm{C}$ within $30 \mathrm{~min}$ of collection. Plasma samples were stored at $-20^{\circ} \mathrm{C}$ until analysis. The concentrations of progesterone in plasma samples were measured by radioimmunoassay as described previously (Flint, Anderson, Patten \& Turnbull, 1974). The sensitivity of the assay, defined as the mass of progesterone resulting in a response 2 s.d. from the zero dose response, was $10 \mathrm{pg} / \mathrm{ml}$.

Within 5-10 min after the end of the infusion period the ewes were stunned using a captive bolt and killed by exsanguination: the fetal lambs were killed by an overdose of pentobarbitone. The cervix was removed and taken to the laboratory on ice where each sample was trimmed free of vaginal and parametrial tissues and weighed. The cervix was opened longitudinally to expose the folds of tissue which project into the lumen and a $15 \mathrm{~mm}$ transverse section, including the central fold, was cut to obtain a strip comprising the whole width of the cervix. Tissue parallel to this central strip was then minced with scissors, dried in acetone and used to determine the total dry weight.

The mechanical properties of the cervix were examined using an adaptation of the apparatus originally described by Harkness \& Harkness (1959). A fuller description of this method, including a critical discussion of the significance of the measurements, has been presented by Hollingsworth (1981). The strip of central cervical tissue was mounted between two clamps and bathed in KrebsHenseleit solution (Krebs \& Henseleit, 1932) maintained at $37^{\circ} \mathrm{C}$ and bubbled continuously with a $95 \% \mathrm{O}_{2} / 5 \% \mathrm{CO}_{2}$ gas mixture. A load of $175 \mathrm{~g}$ was applied to the strip by means of an inextensible nylon-coated glass-fibre cord (breaking strain $4.5 \mathrm{~kg}$ ) passing from the balance pan over a pulley to the upper clamp, the lower clamp being fixed. The axle of the pulley was formed from a multiturn wirewound variable resistor (RS Components, London, U.K.). The pulley was rotated as the cervical strip extended under the load, and the change in resistance modified the current passing through an amplifier to a chart recorder. When the load was applied there was an initial rapid phase of extension followed by a prolonged slow linear increase in length. The gradient of this linear portion $(K)$ and the initial length at the time of loading $\left(l_{0}\right)$ (as determined by extrapolation of this line to the vertical axis), were used to calculate the extensibility or 'rate of creep' of the tissue (E) using the formula $\mathrm{E}=\mathrm{K} / \mathrm{l}_{0}\left(\mathrm{~min}^{-1}\right)$.

\section{Results}

Text-figure 1 shows the increase in length of cervical strips from control and experimental sheep. PGE-2 treatment significantly affected the gradient, initial length and rate of creep (Table 2).

There were no significant patterns of change in concentrations of plasma progesterone during infusion and the mean \pm s.e.m. final value (in samples taken immediately before death) was 109 $\pm 11 \%$ of the mean preinfusion concentration in the experimental sheep $(\mathrm{N}=6)$, and $116 \pm 10 \%$ in the control sheep $(\mathrm{N}=5)$.

Records of amniotic fluid pressure taken before and during infusion with PGE-2 or saline showed no evidence of increased uterine activity. 


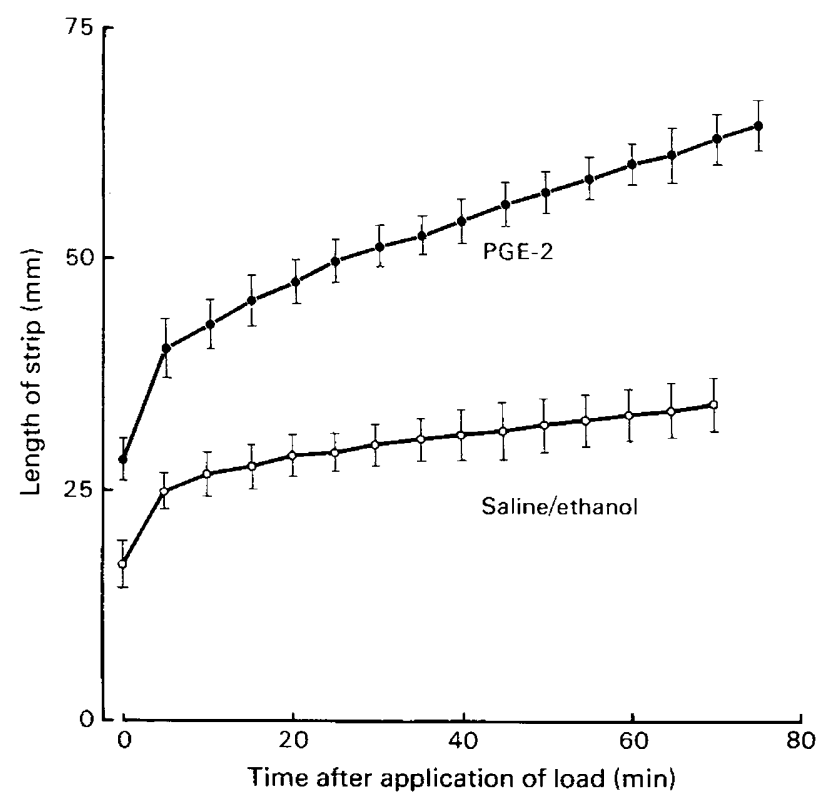

Text-fig. 1. Results of creep tests performed on cervical strips collected from 6 ewes treated with PGE- 2 and 5 ewes treated with saline/ethanol. Readings were taken at 5-min intervals, and values are mean \pm s.e.m.

Table 2. Properties of the cervix of late pregnant ewes after infusion of PGE-2 (10 mg) or control solution (ethanol and saline)

\begin{tabular}{lccc}
\hline & Saline & PGE-2 & Significance* \\
\hline No. of ewes & 5 & 6 & \\
Gradient $(\mathrm{k}, \mathrm{mm} / \mathrm{min})$ & $0.08 \pm 0.01$ & $0.32 \pm 0.05$ & $P<0.002$ \\
Initial length $\left(\mathrm{l}_{0}, \mathrm{~mm}\right)$ & $27.9 \pm 2 \cdot 7$ & $41 \cdot 2 \pm 3.6$ & $P<0 \cdot 02$ \\
Rate of creep $\left(\mathrm{E}, \mathrm{min}^{-1}\right)$ & $2.84 \times 10^{-3} \pm 0.3 \times 10^{-3}$ & $8.6 \times 10^{-3} \pm 1 \cdot 8 \times 10^{-3}$ & $P<0.02$ \\
Wet weight $(\mathrm{g})$ & $24 \cdot 8 \pm 0.3$ & $30 \cdot 6 \pm 3.5$ & $P>0 \cdot 1$ \\
$\%$ water & $80.7 \pm 1.7$ & $82.5 \pm 0.9$ & $P>0.1$ \\
\hline
\end{tabular}

Values are means \pm s.e.m.

* Mann-Whitney 2 -tailed test.

\section{Discussion}

This study indicates that PGE-2 will soften the cervix of the late pregnant ewe when administered directly to the organ via a catheter implanted in a cervical artery. A $10 \mathrm{mg}$ dose of PGE-2 was chosen on the basis of a preliminary study (Ellwood, 1981) in which a variety of doses were compared.

The present study contrasts with previous work in which PGE-2 was infused into the systemic circulation, thus treating both uterus and cervix (Fitzpatrick, 1977b; Fitzpatrick \& Dobson, 1981). Interpretation of the precise role of PGE-2 in these studies is difficult since it is possible that any effect stemmed from an altered pattern of release of steroids or other prostanoids by the uterus when exposed to PGE-2. While our data cannot positively exclude any change in uterine function, we found that neither progesterone secretion nor myometrial contractility were altered by the 
infusion of PGE-2 into a cervical artery. This suggests that the PGE-2 exerted a direct effect on the cervix and strengthens the idea that PGE-2 may have a primary role in the regulation of cervical softening at term. This suggestion is also supported by the studies of Stys, Dresser, Otte \& Clark (1982) who used late pregnant sheep in which cervical compliance was monitored in vivo during treatment with $30 \mathrm{mg}$ PGE-2 administered in a water-soluble gel into the cervical os. This treatment increased cervical compliance in all cases, although since 3 out of the 8 animals examined progressed into labour shortly afterwards, an indirect effect of PGE-2 in this study cannot be ruled out.

In pregnant rats cervical softening does not necessarily require increased uterine contractions (Hollingsworth \& Gallimore, 1981), and the present results suggest that this is also true for the sheep. Although it is plainly advantageous to link cervical softening with the generation of myometrial contractions in normal parturition, these results indicate that cervical function can be altered separately.

We thank Dr A. B. M. Anderson, Professor A. C. Turnbull and Dr M. Hollingsworth for their help, advice and criticism, and $\mathrm{Mr} \mathrm{T}$. Kuchel for administering anaesthetics. This work was supported by the A.R.C. W.L.L. was the recipient of an M.R.C. Studentship.

\section{References}

Cooke, R.G., Knifton, A., Fitzpatrick, R.J. \& Ward, W.R. (1977) The effects of PGF- $2 \alpha$ on uterine motility in surgically aborted goats. J. Reprod. Fert. 50, 167-170.

Ellwood, D.A. (1981) The uterine cervix in pregnancy and at parturition. D.Phil. thesis, University of Oxford.

Ellwood, D.A., Mitchell, M.D., Anderson, A.B.M. \& Turnbull, A.C. (1979) A significant increase in the in vitro production of prostaglandin $E$ by ovine cervical tissue at delivery. $J$. Endocr. 81, 133P-134P.

Ellwood, D.A., Mitchell, M.D., Anderson, A.B.M. \& Turnbull, A.C. (1980a) Specific changes in the in vitro production of prostanoids by the ovine cervix at parturition. Prostaglandins 19, 479-488.

Ellwood, D.A., Mitchell, M.D., Anderson, A.B.M. \& Turnbull, A.C. (1980b) The in vitro production of prostanoids by the human cervix during pregnancy: preliminary observations. Br. J. Obstet. Gynaec. 87, $210-214$.

Ellwood, D.A., Anderson, A.B.M., Mitchell, M.D., Murphy, G. \& Turnbull, A.C. (1981) Prostanoids, collagenase and cervical softening in the sheep. In The Cervix in Pregnancy and Labour, pp. 57-73. Eds D. A. Ellwood \& A. B. M. Anderson. Churchill Livingstone, Edinburgh.

Fitzpatrick, R.J. (1977a) Changes in cervical function at parturition. Annls Rech. vet. 8, 438-449.

Fitzpatrick, R.J. (1977b) Dilatation of the uterine cervix. In The Fetus and Birth (Ciba Fdn Symp. No. 47), pp. 31-47. Eds J. Knight \& M. O'Connor. Elsevier, Amsterdam.

Fitzpatrick, R.J. \& Dobson, H. (1981) Softening of the ovine cervix at parturition. In The Cervix in Pregnancy and Labour, pp. 40-56. Eds D. A. Ellwood \& A. B. M. Anderson. Churchill Livingstone, Edinburgh.

Flint, A.P.F., Anderson, A.B.M., Patten, P.T. \& Turnbull, A.C. (1974) Control of utero-ovarian venous prosta- glandin F during labour in the sheep: acute effects of vaginal and cervical stimulation. J. Endocr. 63, 6787.

Harkness, M.L.R. \& Harkness, R.D. (1959) Changes in the physical properties of the uterine cervix of the rat during pregnancy. J. Physiol, Lond. 148, 524-547.

Hollingsworth, M. (1981) Softening of the rat cervix during pregnancy. In The Cervix in Pregnancy and Labour, pp. 13-33. Eds D. A. Ellwood \& A. B. M. Anderson. Churchill Livingstone, Edinburgh.

Hollingsworth, M. \& Gallimore, S. (1981) Evidence that cervical softening in the pregnant rat is independent of increasing uterine contractility. J. Reprod. Fert. 63, $449-454$.

Hollingsworth, M., Gallimore, S. \& Isherwood, C.N.M. (1980) Effects of prostaglandins $F-2 \alpha$ and $E-2$ on cervical extensibility in the late pregnant rat. $J$. Reprod. Fert. 58, 95-99.

Krebs, H.A. \& Henseleit, K. (1932) Untersuchungen uber die hanstoffbildung in kierkörper. Hoppe-Seyler's $Z$. Physiol. Chem. 210, 72-73.

Liggins, G.C., Fairclough, R.J., Grieves, S.A., Forster, C.S. \& Knox, B.S. (1977) Parturition in the sheep. In The Fetus and Birth (Ciba Fdn Symp. No. 47). pp. 530. Eds J. Knight \& $M$. O'Connor. Elsevier, Amsterdam.

Mitchell, M.D. \& Flint, A.P.F. (1978) Use of meclofenamic acid to investigate the role of prostaglandin biosynthesis during induced parturition in sheep. $J$. Endocr. 76, 101-109.

Stys, S.J., Dresser, B.L., Otte, T.E. \& Clark, K.E. (1982) Effect of prostaglandin E-2 on cervical compliance in pregnant ewes. Am. J. Obstet. Gynec. 140, 415-419. 